\section{B A Institute of \\ YK Business Administration \\ 光 \\ Karachi \\ Leadership and Ideas for Tomorrow}

\section{Business Review}

Volume 2 Issue 2 July-December 2007

7-1-2007

\title{
Research: PIDE Policy Viewpoint
}

Vice Chancellor .

PIDE

Follow this and additional works at: https://ir.iba.edu.pk/businessreview

Part of the Development Studies Commons, Public Affairs, Public Policy and Public Administration Commons, Public Economics Commons, Urban, Community and Regional Planning Commons, and the Urban Studies and Planning Commons

(c) (i)

This work is licensed under a Creative Commons Attribution 4.0 International License.

\section{Recommended Citation}

., V. (2007). Research: PIDE Policy Viewpoint. Business Review, 2(2), 150-161. Retrieved from https://doi.org/10.54784/1990-6587.1395

This article is brought to you by iRepository for open access under the Creative Commons Attribution 4.0 License and is available at https://ir.iba.edu.pk/businessreview/vol2/iss2/10. For more information, please contact irepository@iba.edu.pk. 


\section{RESEARCH}

\section{PIDE Policy Viewpoint}

\section{PIDE Policy Viewpoints are carefully selected by the Vice- Chancellor and Staff of the PIDE to convey important policy messages arising from $P I D E$ research}

\section{RENEW CITIES TO BE THE ENGINES OF GROWTH}

DIDE Cities Research Programme was initiated in Karachi with a conference titled Cities: the Engine of Growth on November 15-16, 2006. The conference was held in our largest city and was well-attended by economists, architects, town planners, Nazims, government officials, NGOs, journalists, and other citizens. The discussion was animated and about twenty-five speakers addressed the gathering. All points of view were represented and debated.

The main points of the discussion that took place there may be summarised as follows:

- All segments of our society are dissatisfied with the current state of our cities and with every aspect of our cities from their management to what they offer. None of their needs seem to be met by these cities.

- The debate on cities has not happened nor has anybody developed any research or fresh thinking on the subject.

- How cities are managed and who manages them is not clear and this seems to render the citizens powerless and voiceless. The continuing problems with the recent decentralisation and the inability to define city administration in the presence of the army cantonments in cities compounds problems of city administration and citizen's participation in that administration.

Several important themes were developed in the conference which will form the basis of future research and debate.

\section{LEARNING FROM RESEARCH AND EXPERIENCE OF THE REST OF THE WORLD}

History and civilisation moves in cities. All major scientific, social, political, economic and technological innovations have happened in human agglomerations known as cities. Great civilisations and empires have been developed around cities. It is no accident that the dominant empire of any time had the most important, creative and fascinating city of the time.

The best cities have been places of learning and idea development. Cities such as London, Edinburgh, Paris, Los Angeles and New York have been a birthplace of 
invention and creativity. Measured productivity increases in large, well-organised, and creative cities.

The bulk of the output in any country is produced in the cities. The difference between the poor and the rich countries often lies in the productivity of their cities.

In the post-industrial information age, creativity creates value. Creative cities enhance individual productivity. Creative cities are multi-ethnic, open to immigration, culturally rich, dense, full of learning and innovation, allow for eccentricity, and offering many and diverse learning experiences.

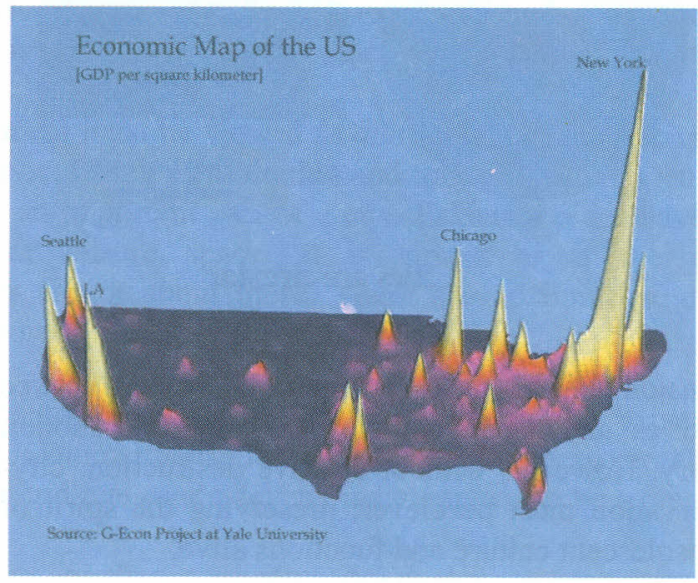

Cities allow space for everyone and all activities. All classes live in cities. Often the poor and middle class live in cities while the rich estates move to open suburban environments. Cities offer community and networking infrastructurelibraries, community centres, sporting and conference facilities and theatres-to all, especially the poor and the middle classes.

The young, the poor and the middle classes along with their creative activities live with businesses in busy 24-hour downtowns. These city centres are the heart of a city and define a city. All development around a city is then relative to this city centre. City centres are a magnet for ideas and migration. In fact globalisation is really the network of ideas generated in city centres.

\section{UNDERSTANDING CITIES}

All human activity leads to conflicts which civilised societies seek to manage. Cities are dense human settlements and it is no wonder that they accentuate all conflicts. Successful countries and city administrations develop institutions for managing these 
conflicts bearing in mind the needs of development and growth. Where conflicts are not properly managed, decline sets in.

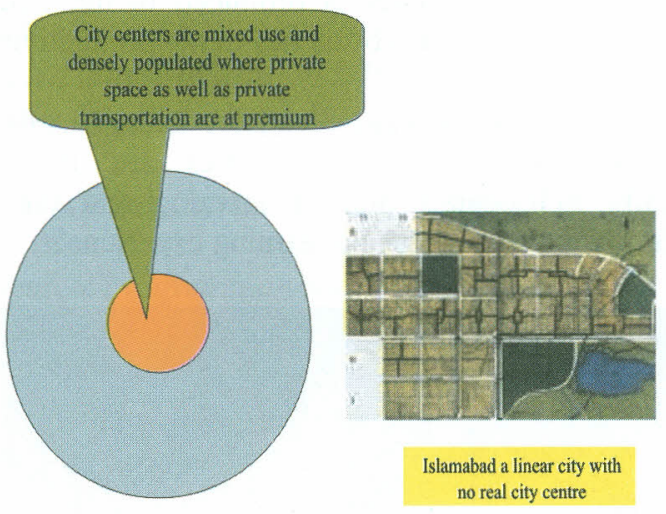

Cities are circular

One important tension that needs to be managed is that between preservation of legacies and histories and accommodating the new and modern. Preservation is costly but necessary. However, without creative destruction, city development may be arrested. Preservation must be clever, preserving the spirit of the past and not seeking to keep obsolescent culture and functions alive.

Incumbents have the first mover advantage in any city occupying the best land and the use of the main amenities of cities like clubs and parks. Unless city management is looking toward development, these incumbents will use the preservation argument to preserve more than is necessary and most of the preservation will be self-serving.

Mayor Koch of New York talked of the NIMBY ("not in my backyard") mentality. Most of us would like a nice spacious mansion set in the middle of nice green meadows with all urban amenities within easy reach. Yet no one wants a busy highway or a shipping mall close to their backyard. Yet as a city grows, space has to be made for urban conveniences such as highways, hotels, offices and shopping malls. Often estates and even palaces have to give way to the development of the city. City management must be able to deal with NIMBY saying.

Palaces, estates, hunting grounds, and leisure parks of the rich have given ground to the needs of the city. Even kings and dukes have seen the importance of yielding such private spaces to the development of more productive cities. 


\section{CHARACTERISTICS OF PAKISTANI CITIES}

1. All Pakistani cities appear to have no downtowns or city centres - dense areas of mixed use concentrating residential, office, commercial and entertainment within an almost walkable district.

2. There is an excess demand for most forms of city activities - education, entertainment, office, retail, warehousing and even poor and middle class housing. All these activities lack purpose-built space and are forced to be conducted in the only kind of city space that planners have been allowing for the last few years - houses. Housing for the poor, the young starting family, and the middle class is also in short supply since flats are not allowed to be built.

3. City management must be viewed as more than providing physical infrastructure and basic services such as sanitation and transport. Social, cultural, and learning activities are an important part of a city. Pakistani cities have no entertainment, community or leisure space. It is almost as if the planners and city administrators forgot about these. There are no libraries, community centres, theatres or sporting facilities (except for the élite).

4. Zoning seems to favour large housing often at the expense of commercial development. Commercialisation is arbitrary, cumbersome and expensive. As a result, zoning and real estate development appears to be a rent-seeking game.

5. Government rather than commerce dominates the city everywhere. There is a large presence of government especially the army in all cities. Most prime land is government-owned, making the availability of prime land for commercial and mixed use development very difficult. ${ }^{1}$

6. Resources for city development remain scarce not the least because prime city land remains extremely poorly utilised. Quality development, such as hotels, shopping malls convention centres are considered a nuisance probably in deference to the NIMBY-sayers. Even when entertainment facilities are built such as the stadiums in many cities, government officials manage them to minimise their use rather than maximise profits and activities. Over time, shops creep up into the walls of the stadium so that eventually it is neither a stadium nor a shopping mall (e.g., Fortress Stadium, Lahore).

\footnotetext{
'For example, the Mall Road, Lahore, the main thoroughfare, is completely owned by the government almost all the way from the Provincial Assembly chambers to the Airport.
} 
7. Since density in city centres is not considered desirable, disorderly suburban development is taking place. Many cities are becoming urban sprawls at the expense of valuable agricultural land.

\section{DECENTRALISATION, CITY MANAGEMENT, AND RENT-SEEKING}

Why are our cities in such poor shape? The answer was identified to lie in the architecture of their governance.

- Neither the city administration, nor the citizens of the city have much say in the running, or in determining the character of their cities. Too many government agencies are involved in these decisions. Cantonments cut across cities and are not a part of them preventing integrated development.

- Federal and provincial governments own vast amounts of inner city land which is arbitrarily developed without consultation with the City. ${ }^{2}$

- Key city services which should be a part of city administration such as health, education, and law and order are provided by federal and provincial administrations.

Cities have become a major vehicle of rent-seeking and privilege preservation. Zoning and the arbitrary use of public land has through history been a major vehicle for rent distribution. Laws and institutions-based on open transparent processes and clear property rights - have been created to deal with this problem. In Pakistan centralised administration, opaque processes and inadequate city administrations have heightened rent-seeking activity stifling city economic growth while accelerating speculation.

\section{WHAT SHOULD BE DONE?}

We have learnt that "Cities grow when they are allowed to function as decentralised, coherent administrative units that are run for the advancement of commerce. It is then that they are engines of economic, cultural and human growth". To achieve this:

- Policy, research and thinking needs to move away from a spaceless approach to development by integrating the role of cities as engines of growth.

- Decentralisation needs to be strengthened to allow cities adequate ownership of their land and resources. This must mean an adequate definition of city limits with exclusive city ownership of its resources.

- Federal, provincial governments, and the defense agencies should not affect city administration.

\footnotetext{
${ }^{2}$ Examples abound: arbitrary offices, leisure clubs, and training academies that the Punjab government and various federal agencies have built up in Lahore without consultation.
} 
- Fiscal federalism needs to be urgently adopted for city growth.

- The zoning paradigm needs to move away from its current emphasis on upper class housing to one that recognises the diversity of the functions of a city.

- City centres need to be developed for dense mixed use. Government ownership of city-centre land needs to be reduced if it is retarding downtown development. Commerce is to be given priority in city centres.

- Zoning needs to be based on clear transparent processes based on open citizen consultations.

- Culture and education need to be included in zoning. ${ }^{3}$

- City management should be professional, consultative and accountable. Cities must be able to hire out of their budgets without federal hiring restrictions such as the Unified/National Pay Scales and mandatory positions for the federal civil service. Moreover, decision-making must be based on open consultative processes.

This simple reform agenda will reduce the current high level of rent-seeking in our cities and lay the basis of commerce and creativity which will fuel sustainable growth.

\section{ESTABLISHING PROPERTY RIGHTS THROUGH A SECURE SYSTEM OF LAND TITLE MANAGEMENT}

\section{INTRODUCTION}

Land is a critical economic asset in any economy. The need for a timely, accurate, safe, simple, secure, and universally accessible system of registering and recording land transactions and interest in land is the cornerstone of a proper land market. Such land markets are an important mechanism to empower the poor and reduce the costs of doing business. ${ }^{4}$ Secure property rights provide asset owners the incentive to invest in their property while allowing easier collateralisation. Without secure tradable property rights, land is 'dead capital'.

Even in Pakistan, where titles are clear and transfers are easy, land prices command a premium. For example, Defence Housing Authority (DHA) properties are appreciably higher than similar properties in the same city. This is mainly because people have faith in the title and its transferability (even when we account for better planning and management).

\footnotetext{
${ }^{3}$ Currently while we build leisure clubs for the privileged routinely, there is no space for libraries, theatres, community centres, museums and art galleries.

${ }^{4}$ See Hernando De Soto, The Other Path: The Economic Answer to Terrorism. New York: Perseus Books, 1989, 2002. Also, Hernando De Soto, The Mystery of Capital: Why Capitalism Triumphs in the West and Fails Everywhere Else. New York: Basic Books, 2000, 2003.
} 


\section{A REVENUE RECORD AND NOT A TITLE}

The records-of-rights in land in Pakistan are of the fiscal variety. The person shown on the records is responsible for paying land revenue or property tax, and is, consequently, presumed to be the owner, unless it can be proved to the contrary. The title to land, therefore, is only incidental.

Modern methods of record-keeping, initiated by the British, were dictated by the need for revenue. Tax on agricultural land, an important source of government revenues, required identification of those responsible for paying it. The record, updated to reflect changes of ownership, was and continues to be maintained by one central agency in the provincial government, the Board of Revenue. It was for this reason that, over time, a presumption of truth became attached to this record and it had become the principal source/document deciding the title of agricultural land. These records still constitute the principal documentation of title on agricultural land, even though land revenue has declined in significance; and there are problems in the accuracy, completeness, and currency of these records.

In the urban areas, however, there is no single agency keeping a conclusive record of rights of properties. A number of entities have been created over time to administer urban land. Each one of them has evolved its own practices and procedures to record ownership and the changes in it. This is quite different from the system in place in rural areas, where only the Board of Revenue maintains the record of rights in agricultural land.

Pakistani law does not admit of the provision of a certificate from the government guaranteeing that the person mentioned in the records-ofrights is the true owner. In other words, if the records were to be proved wrong later, the state could not be taken to court and a suit filed against it. The records-of-rights in land and other legal provisions suggest a structure, at least in theory, of records in which all transactions are noted. The entries in respect of transactions are not viewed as conclusive evidence, although these may be viewed, in the courts of land, as having a presumptive status; the records are regarded as prima facie evidence.

The entries in the records-of-rights can be challenged in courts since there is no guarantee of title envisaged in the law. The Transfer of Property Act also does not envision that the state will guarantee title to property. The documents of title provided by the vendor to the vendee do not certify title; they are private documents relating to a transaction between private parties confirming only one transaction in an entire chain of transactions. The registrar by entering the transaction in the official records only confirms the validity and accuracy of the document; he does not thereby give any assurance of title to the transferrer of the property. 


\section{REGISTRATION}

Furthermore, the Registration Act envisages the registration of documents and not the registration of titles. The Registrar registering a document records a transaction but does not guarantee that the transaction is valid. According to Rule 135 of the Registration Rules, 1929, it is not the concern of the Registrar to establish the validity of a document. In fact, he cannot even refuse to register a document on the grounds that it is a fraudulent transaction since the executor was dealing with a property not owned by him. The Registrar is neither empowered nor required to question the transaction. Not only is the Registration Office not supposed to go into questions of title, the legality of transactions and the validity of the document, the Office is expressly forbidden by law to concern itself with these issues. It is in essence a government revenue collecting agency, and that is how the framers of the rules see it.

Moreover, oral declarations of gift, under Islamic law, do not have to be registered. The same is the case for wills. Thus, perfectly valid titles can be created without the transaction being recorded anywhere. Any search by a buyer at the Revenue Record and the Registrar's Office will not provide any clues to such a transaction.

And the courts maintain that registered land documents or receipts of property tax in the name of the person do not ensure title but only serve as evidence to a title which is taken into consideration when scrutinising the bonafides of a person claiming to have a 'legal' title.

Moreover, Pakistani law also recognises that a person mentioned in the record of rights may not be the actual owner. The property may have been purchased by one person (benamidar) ${ }^{5}$ in the name of the owner on record (benami) $3^{6}$ for a number of reasons - to avoid tax, to defraud creditors, or to avoid fragmentation of property on account of the Islamic law of inheritance. Under the Benami Law of Transactions (a common law) the court recognises the right of the purchaser of the property to claim that the land actually belongs to him by claiming that the person mentioned in the record or the document had not paid any consideration for the property and was only holding it for him in the capacity of a trustee.

\section{TRADITIONAL SYSTEM OF CONVEYANCING}

The established system of conveyancing visualises that the buyer must investigate the seller's title to the property - "let the buyer beware". Despite the exercise of due caution, the title may still be defective. The reason is that although the buyer may have satisfied himself of the authenticity of the transactions leading to the present

\footnotetext{
${ }^{5}$ Urdu legal word indicating the holder of the deed without the title

${ }^{6}$ Urdu legal word for the deed without the title.
} 
transaction, it is just possible that some of the documents of the earlier transactions were defective on account of forgery, lack of consent, consent granted by a minor and hence not valid, etc. In other words, the document merely records a transaction but does not prove that the parties named in the document have the legal right to enter into such a transaction, i.e., the validity of the transaction is not guaranteed by the document and the certified copy of the deed. For example, the names of legal successors may not have been recorded in the records-of-rights in land. Hence, many legal owners do not have possession, while many of those in possession do not have their names recorded in the relevant registers of rights in land. The result, as we all know, is never-ending litigation and the overburdening of the judicial machinery.

\section{NEED FOR STATE GUARANTEES OF TITLE TO PROPERTY}

Given the growing pressure of population on land, as well as the Islamic law of inheritance, the demand for land and the disputes over title will increase, and with these the importance of the certainty of title.

Even if we were to have a record of deeds, it would not record matters which impact upon title. For instance, succession on death provides title by the operation of law and not because of a transaction between two parties. The government should, therefore, set up a system of guaranteeing title to land rather than a system that merely serves the purpose of registration of documents.

\section{ADVANTAGES OF STATE GUARANTEES TO TITLE}

If the government were to develop a system of guaranteeing title, it would not be of benefit to those involved in land transactions only. By tackling insecurity of title and by enhancing the marketability of land, it would be possible to reduce the workload of the courts to settle title disputes, enable implementation of land reforms, facilitate credit availability to small farmers, generate tax revenues by providing information that can be used to check evasion of income tax, and prevent cost and time overruns in development projects involving land acquisition.

The importance of modern technology and the introduction of a GIS are universally recognized as a way of enabling quick and efficient recording of title transfers. It may initially turn out to be an expensive proposition, for example, on account of indemnification losses. The costs, however, if they are not largely met from increased tax revenues, can be minimised by setting up a special fund to begin with, which can be supplemented by registration charges as transactions get recorded. This route provides the only lasting solution to the problems discussed above. Only those who are profiting from the poorly maintained records - i.e., the officials maintaining them and the property brokers-will oppose an up-to-date, accessible, system for recording land-related information. 


\section{SYSTEMS IN OTHER COUNTRIES}

These are summarised below for different routes that could be adopted to achieve the same goal- the certainty of title:

THE TORRENS SYSTEM ADOPTED IN AUSTRALIA AND OVER 50 COUNTRIES, INCLUDING KENYA, UGANDA, TUNIS, AND SYRIA

Given below are the important characteristics of the Torrens system whereby the state certifies the authenticity of the title:

(a) the definitive nature of the title is established;

(b) repeated, costly examination, of records is no longer required, simplifying the conveyancing procedures and systems;

(c) the problems created by genuine errors and mistakes in the past can be avoided.

Experience in several Australian states shows that when the central government created a database of all parcels of land and their respective owners, they were able to detect many more legitimate tax-payers.

\section{THE ENGLISH SYSTEM}

The Land Transfer Act in England also requires a compulsory registration of title to land. The registered holder is regarded as the sole owner.

The difference of the English system from the Torrens system (which is much simpler) is that titles can be corrected in the event of fraud. In the Torrens system, the courts have limited, if any, jurisdiction over the records of titles.

\section{THE U.S. SYSTEM}

In the U.S. each of the 3,600 counties has its own system for recording title transactions (these being recording systems and not registration systems), although recording is not necessary for the validity of the instrument. Unlike the Torrens and English systems, the evaluation of the validity and the quality of the title in the U.S. system is the responsibility of private parties using the data in government custody. However, nowadays mortgage underwriters require title insurance for every transaction that they underwrite. As a result, title insurance has almost become universal and title insurance companies have become the usual agencies to conduct title searches. These changes have made the U.S. system similar to the Torrens and English systems with respect to the convenience it brings to buyers on the quality of the title to land. 


\section{RECOMMENDATIONS}

1. We should set up a system of registration of titles-going beyond a project aimed at automation of records of rights to land and transactions in property being tried in the Punjab-and completely scrap the obsolete and dysfunctional systems managed by Patwaris, Tehsildars, Tapedars, and Mukhtiarkars.

2. There is a need to establish a centralized land registry system in the form of a central register of title of urban land-the most expensive and commercially attractive land. The provincial governments should give the responsibility of determining title to such land to the Excise and Taxation Department (E\&T). This Department has the most complete and accurate record of urban properties in the province, and hence best suited to shoulder this burden. To be effective, it should have the legal mandate and the necessary resources in terms of finances, trained manpower, and hardware and software equipment. Moreover, the Registration Department should be bifurcated and the section dealing with urban properties should be placed under the E\&T department. Alternatively, the institutional arrangement proposed above can be placed under the Board of Revenue by establishing a Revenue Authority.

3. As a first step in the long-term strategy to design and implement a system of title registration, there should be a requirement for compulsory registration of all documents relating to property-including sale agreements, declaration of gifts, awards, transfers, and powers of attorney (in the last case, with the Sub-Registrar of the area in which the property is located). Any party claiming title through adverse possession should be required, within six months of acquiring such title, to register their claim. A system of registering deeds can provide the platform on which a system of registering titles can eventually be built.

4. General Powers of Attorney should be abolished altogether.

5. Benami transactions will have to be declared unlawful.

6. Any suit with respect to any immovable property should be compulsorily registered with the Registrar of the High Court. The Registration Act and the Stamp Duty Act should be amended to reflect this. Moreover, by linking court records to the computer database of the Registrar, prospective buyers would be informed that the property is under litigation. 
7. Simultaneously, the government could start a process of converting presumptive titles into exclusive titles after preparing draft lists that would be open to public inspection for a period of 6 months, during which objections and disputes would be settled.

8. One of the main reasons for the long delays in settling title disputes in the courts of law is the system of multiple appeals and revisions-beginning with the court of civil judge to the Supreme Court-even in the case of a small property dispute. This system must be replaced by one in which a party in a civil claim does not have a right of more than one appeal. The final court of appeal should be the High Court, and not the Supreme Court, since property is a provincial subject.

This Policy Viewpoint was prepared by Shahid H. Kardar, Director, Systems (Pvt.) Ltd., Lahore.

References and other material are available on PIDE website: www.pide.org.pk

\section{THINKING SMALL FOR THE FUTURE}

ERIC Drexler gets credit for introducing the concept of nanotechnology in his 1987 book, Engines of Creation which suggests the manufacturing and control on a tiny scale, down to molecular level. This concept immediately found its significance in all areas of science and technology - biological, material and chemical systems are developed by taking advantage of fine control and construction at the minute scale. Nanotube filaments of graphite, discovered by researchers in 1998, exhibit unusual elasticity, strength and control over electric conduction. This discovery will allow computer screens built into the walls and buildings to snap back into shape after the earthquake. Nanotubes are a thousand times lighter and stronger than steel. Just imagine an aeroplane built out of these nanotubes will entirely change the aerodynamic demands of take-off, landing and horizontal flight. A major constraint to this concept is the cost-factor as raw material from which these nanotubes are made is 10 times as expensive as compared to a pound of gold. Though, it is always hard for new materials to make a place in the market but this technology is determined to do just that. 